\title{
Perilaku Kerja Inovatif ditinjau dari Modal Psikologis, Tuntutan Kerja, dan Sumber Daya Pekerjaan
}

\author{
Suci Fadhla Hasanah ${ }^{1}$, P. Tommy. Y. S. Suyasa ${ }^{2}$, dan Fransisca Iriani Dewi ${ }^{3}$ \\ ${ }^{1}$ Program Studi Psikologi, Universitas Tarumanagara, Jakarta \\ Email:Dalimuntesuci@gmail.com \\ ${ }^{2}$ Fakultas Psikologi, Universitas Tarumanagara, Jakarta \\ Email: tommys@fpsi.untar.ac.id \\ ${ }^{3}$ Fakultas Psikologi, Universitas Tarumanagara, Jakarta \\ Email: fransiscar@fpsi.untar.ac.id
}

\begin{abstract}
ABSTRAK
Penelitian ini membahas mengenai hubungan modal psikologis, tuntutan kerja, sumber daya pekerjaan dan perilaku kerja inovatif pada widyaiswara. Tujuan dari penelitian ini adalah untuk melihat variabel mana antara modal psikologis, tuntutan kerja, sumber daya pekerjaan, yang menjelaskan perilaku kerja inovatif. Partisipan pada penelitian ini adalah Widyaiswara pada Kementerian Kesehatan. Berdasarkan path analysis, hasil penelitian menunjukan bahwa perilaku kerja inovatif paling dijelaskan oleh sumber daya dalam pekerjaan (job resource) sebesar $(\mathrm{r}=0.241, \mathrm{p}<0.01)$.
\end{abstract}

Kata kunci: perilaku kerja inovatif, modal psikologis, tuntutan kerja, sumber daya pekerjaan.

\begin{abstract}
This study discusses the relationship between psychological capital, job demands, job resources and innovative work behavior in widyaiswara. The purpose of this study is to see which variables between psychological capital, job demands, job resources in explaining innovative work behavior. Participants in this study were Widyaiswara at the Ministry of Health. Based on the path analysis, the results of the study show that the most innovative work behavior is explained by job resource of $(r=0.241, p<0.01)$.
\end{abstract}

Keywords: innovative work behavior, psychological capital, job demand, job resource.

\section{PENDAHULUAN}

\section{Latar belakang}

Dalam meningkatkan keterampilan, kompetensi dan pengetahuan pada ASN, Pemerintah memfasilitasi dengan memberikan diklat. Diklat yang diberikan pada ASN antara lain; diklat struktural atau kepemimpinan yang dilaksanakan untuk mencapai persyaratan kompetensi kepemimpinan dalam aparatur pemerintahan, diklat fungsional yang dilaksanakan untuk mencapai persyaratan kompetensi yang sesuai dengan jenjang jabatan fungsional masing-masing dan diklat teknis yang dilaksanakan untuk mencapai persyaratan kompetensi teknis yang diperlukan untuk pelaksanaan tugas ASN.

Pelaksanaan diklat membutuhkan widyaiswara. Dalam satu sesi diklat membutuhkan satu widyaiswara. Widyaiswara adalah ASN yang diangkat sebagai pejabat fungsional yang memiliki ruang lingkup, tugas, tanggung jawab dan wewenang untuk mendidik, mengajar dan melatih ASN (Aparatur Sipil Negara). Selain itu, widyaiswara juga berperan sebagai konsultan dalam bentuk implementasi pembelajaran diklat.

Khairani (komunikasi personal, 19 April, 2018) dalam hasil wawancara menjelaskan bahwa widyaiswara dituntut untuk meningkatkan kompetensi dengan mengikuti pelatihan-pelatihan dan biaya disediakan oleh pemerintah. Penilaian widyaiswara terletak pada angka kredit yang akan 
didapatkan pada saat melaksanakan diklat. Penilaian antara lain; keikutsertaan dalam diklat, penyusunan bahan ajar, melakukan tatap muka di kelas, penyusunan modul diklat, dan pemberian bimbingan serta konsultasi.

Pada peraturan Lembaga administrasi Negara (LAN) Nomor 8 tahun 2015 tentang unsur kegiatan dan rincian kegiatan menjelaskan bahwa widyaiswara harus memiliki penemuan inovasi yang dipatenkan sesuai bidang keahliannya. Oleh karena itu diharapkan widyaiswara memiliki kemampuan dalam berinovasi. Sangat penting bagi pengajar untuk menggunakan metode pengajaran inovatif (Naz \& Murad,2017). Perilaku kerja inovatif (innovative work behavior) adalah perilaku yang dimulai sendiri, proses di mana ide-ide baru dihasilkan, dibuat, dikembangkan, diterapkan, dipromosikan, direalisasikan, dan dimodifikasi oleh pengajar agar bermanfaat (Konermann dikutip dalam Thurlings, Evers dan Vermaulen, 2014).

Fay, Bagotyriute, Urbach, West dan Dawsen (2017) menjelaskan bahwa perilaku kerja inovatif diprediksi oleh tuntutan kerja (job demand). Dalam penelitian Fay et al. (2017) dijelaskan bahwa semua jenis pemicu stres dapat memicu perilaku inovatif. Dengan kata lain, perilaku inovatif sering kali merupakan akibat dari tuntutan kerja yang tinggi. Hal ini dapat terjadi kemungkinan karena individu mengimplementasikan suatu inovasi untuk mengubah situasi. Berdasarkan penelitian (Fay et al., 2017) terdapat hubungan postif antara tuntutan kerja dan perilaku kerja inovatif.

Namun demikian tuntutan kerja tidak berdiri sendiri diikuti dengan sumber daya pekerjaan. Menurut Dedidu, Leka, dan Jain (2018) menjelaskan bahwa tuntutan kerja secara bersamaan dengan sumber daya pekerjaan dalam memprediksi perilaku kerja inovatif. Oleh karena itu hasil penelitian Fay et al. (2017) ditinjau dari tuntutan dan sumber daya dalam pekerjaan (job demand-resources). Job Demand-Resources yang dikemukakan oleh Dedidu, et al. (2018) menjelaskan bahwa sumber daya dalam pekerjaan dapat menyangga dampak dari tuntutan kerja antara lain adalah kelelahan dalam pekerjaan. Sumber daya dalam pekerjaan seperti dukungan antar kerja dan dukungan atasan dapat mengarahkan individu untuk menciptakan keterampilan dan berinovasi (Dedidu, et al. 2018).

Lain halnya dengan Mishra, Bhatnagar, Gupta dan Wadsworth (2017) menjelaskan bahwa perilaku kerja inovatif diprediksi oleh modal psikologis (psychological capital). Modal psikologis yang dicirikan dengan hope, self-efficacy, optimism dan resilliency. Hasil penelitian Mishra et al. (2017) menujukan adanya hubungan positif dan signifikan antara psychological capital dan innovative work behavior.

Masih sedikit penelitian yang menjelaskan bahwa modal psikologis, tuntutan kerja dan sumber daya pekerjaan secara bersamaan dalam memprediksi perilaku kerja inovatif. Senada dengan hal tersebut hanya ada beberapa studi kuantitatif tentang hubungan antara job demand-resource dan perilaku inovatif (Martin, Salanova, \& Peiro, 2007). Hal tersebut memperlihatkan bahwa individu yang dapat mempertahankan cara kerjanya walaupun tuntutan pekerjaan tinggi dapat megalami perilaku inovasi.Selain itu hal positif dalam diri dan kepercayaan diri yang membuat individu memiliki perilaku inovatif. Hal ini juga terjadi pada widyaiswara yang dituntut untuk berperilaku inovasi dalam mengembangkan pelatihan.

Berdasarkan uraian diatas, penelitian ini akan membahas mengenai hubungan modal psikologis, tuntutan kerja, sumber daya pekerjaan dan perilaku kerja inovatif pada widyaiswara. Mengingat perilaku inovasi yang dimiliki oleh widyaiswara dapat dilihat dari kondisi positif yang ada pada diri mereka atau terkait dengan sumber daya dalam pekerjaan yang dapat mengurangi tuntutan kerja. 


\section{Perilaku kerja inovatif}

Perilaku kerja inovatif adalah suatu perilaku kerja yang bertujuan untuk menghasilkan, memperkenalkan dan menerapkan hal-hal baru yang bermanfaat bagi perusahaan (West \& Farr dalam De Jong \& Kemp, 2003). Hal-hal baru yang dimaksud pada konteks perilaku kerja inovatif dapat meliputi ide, proses, prosedur maupun produk baru. Perilaku kerja inovatif ini dapat tercapai melalui pemanfaatan pengetahuan dan pengalaman yang dimiliki individu guna menghasilkan suatu ide, proses maupun solusi baru (Amabile dalam He, 2013).

West dan Farr (dalam De Jong \& Kemp, 2003) menambahkan bahwa hanya perusahaanperusahaan yang terampil berinovasi dan sukses mengeksploitasi ide-ide baru, yang akan mendapatkan keunggulan persaingan di pasar dunia yang berubah-ubah dengan cepat ini dan mereka yang tidak terampil akan ketinggalan. Zaltman, Duncan dan Holbek (dalam Scott \& Bruce, 1995) menyatakan bahwa inovasi dalam suatu organisasi adalah proses perubahanyang menghasilkan produk, proses atau prosedur baru bagi organisasi. Oleh karena itu perilaku kerja inovatif menjadi sebuah komponen perilaku yang penting untuk dimiliki oleh karyawan dalam sebuah perusahaan.

\section{Modal psikologis}

Modal psikologis (psychological capital) adalah suatu pendekatan untuk mengembangkan dan mengoptimalkan fungsi psikologis yang positif pada individu. Modal psikologis berfokus pada pembentukan kekuatan dan kebajikan yang akan memungkinkan individu untuk puas dengan diri mereka dan pekerjaan mereka (Wu, 2015).

Luthans, Avolio, Avey dan Norman (dikutip dalam Pillay, Buitendach, \& Kanengoni, 2014) mengatakan bahwa modal psikologis adalah perkembangan konstruksi dari literatur psikologi positif. Sedangkan (Lee et al dalam Ajum, Ahmed, \& Karim, 2014) berpendapat bahwa modal psikologis dan ketenangan pikiran adalah sumber daya psikologis yang berkontribusi pada pencapaian fungsi intra-psikis dan interpersonal yang adaptif yang menghasilkan pola pikir dan keyakinan positif. Semakin banyak bukti ilmiah juga memverifikasi nilai dari kepositifan ini dalam diri individu, kesejahteraan, dan perilaku terkait pekerjaan.

\section{Tuntutan dan sumber daya pekerjaan ( Job demand-resources)}

Tuntutan kerja didefinisikan sebagai tuntutan pekerjaan yang menjadi pemicu terjadinya kelelahan secara psikologis, misalnya seperti: bekerja secara non-stop dalam jam kerja yang lama, beban pekerjaan yang terlalu banyak dan terbatasnya waktu yang diberikan untuk menyelesaikan pekerjaan tersebut, dan adanya konflik pada tuntutan pekerjaan yang harus diselesaikan (Peter, Love, Irani, \& Standing, 2007).

Schaufeli dan Bakker (2004) menyatakan tuntutan kerja adalah aspek-aspek fisik, psikologis, sosial dan organisasi dari pekerjaan yang membutuhkan usaha dalam bentuk fisik, kognitif maupun emosional secara terus menerus. Oleh karena itu, hal ini diasosiasikan dengan biaya fisik atau psikologis tertentu. Meskipun demikian, tuntutan kerja tidak selalu menghasilkan efek negatif, tetapi tuntutan kerja dapat berubah menjadi stres kerja bila disertai dengan tuntutan yang membutuhkan usaha yang besar, yang pada akhirnya dapat menimbulkan efek negatif seperti depresi, dan kecemasan.

Sumber daya dalam pekerjaan adalah aspek-aspek fisik, psikologis, sosial, atau organisasi dari pekerjaan yang mengurangi tuntutan pekerjaan, mengurangi biaya fisiologis dan psikologis yang 
terkait pekerjaan, fungsional dalam mencapai tujuan kerja, dan merangsang pertumbuhan pribadi, pembelajaran, dan pengembangan (Bakker, Demerouti, Hakanen \& Xanthopoulou, 2007).

\section{Peran modal psikologis, tuntutan kerja, dan sumber daya pekerjaan terhadap perilaku kerja inovatif}

Peran modal psikologis, tuntutan kerja, dan sumber daya pekerjaan terhadap perilaku kerja inovatif dijelaskan kedalam konsep conservation of resources (COR). Teori conservation of resources berpendapat bahwa individu memiliki motivasi dasar untuk memperoleh, mempertahankan, melindungi, dan meningkatkan sumber daya psikologis mereka. Sumber daya yang terdapat pada individu antara lain; karakteristik pribadi (misalnya, self-efficacy, pencapaian tujuan), objek (misalnya, buku, komputer), kondisi (misalnya, sistem pendukung, peringkat), dan energi (misalnya, (misalnya, waktu, uang) (Westman et al. 2010).

Modal psikologis dalam konsep COR diidentifikasi sebagai sumber daya karakteristik pribadi yang dapat meningkatkan kemampuan individu dalam menanggulangi masalah dalam keadaan stres. Individu yang memiliki modal psikologis mampu menggantikan sumber daya yang digunakan dalam menangani tuntutan dalam situasi yang penuh tekanan, dan dengan demikian kurang dalam mengalami stres. Oleh karena itu, modal psikologis dapat dikonseptualisasikan sebagai sumber daya psikologis pribadi dan akan memungkinkan karyawan untuk menghadapi tantangan, stres, insiden, atau kekerasan (Siu, 2013).

Teori COR (Woerkom, Nishi, \& Bakker,2016) menjelaskan bahwa kehilangan sumber daya dalam pekerjaan diakibatkan dari tuntutan pekerjaan tinggi, dapat menyebabkan melemahnya cadangan sumber daya untuk menghadapi jenis permintaan pekerjaan lain. Individu biasanya berusaha untuk membangun, melindungi, dan mempertahankan karakteristik pribadi, kondisi, dan energi yang memungkinkan mereka untuk mengatasi tuntutan pekerjaan. Sejalan dengan konsep COR (Westman et al, 2010), individu yang mengalami tuntutan kerja akan memperluas sumber daya yang tersisa dan modal psikologis dengan perilaku kerja yang inovatif untuk mendapatkan sumber daya baru, seperti peningkatan dalam kondisi kerja, kesehatan. lingkungan kerja atau perkembangan karir.

Berdasarkan kerangka berpikir di atas, maka hipótesis dalam penelitian ini adalah sebagai berikut:

H1 : Modal psikologis berhubungan dengan perilaku kerja inovatif

$\mathrm{H} 2$ : Tuntutan kerja berhubungan dengan perilaku kerja inovatif.

H3 : Sumber daya pekerjaan berhubungan dengan perilaku kerja inovatif.

Berdasarkan uraian di atas, maka kerangka berpikir penelitian ini adalah sebagai berikut: 


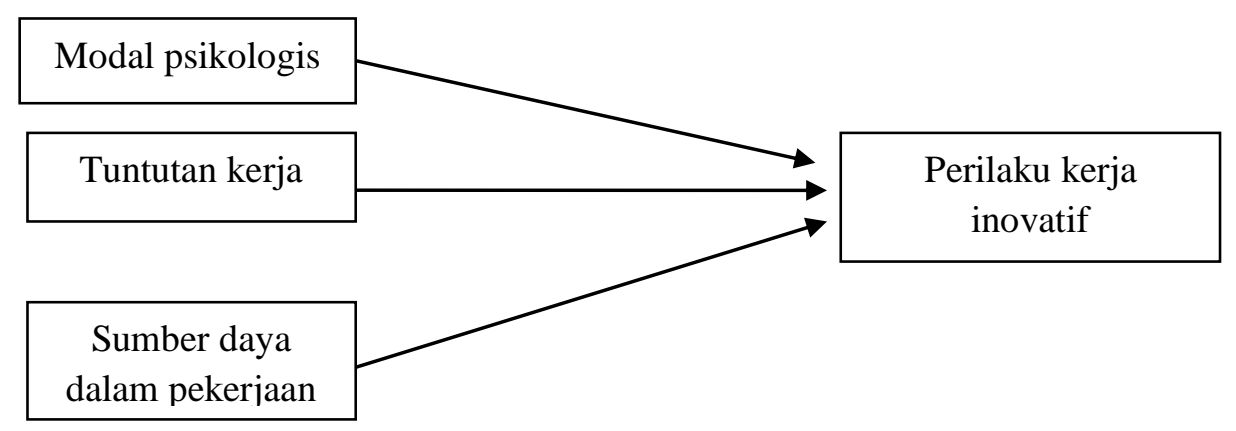

Gambar 1: Kerangka Berpikir

\section{METODE PENELITIAN}

\section{Partisipan penelitian}

Individu yang menjadi partisipan dalam penelitian ini adalah widyaiswara pada Badan Pelatihan Kesehatan di Kementrian Kesehatan. Peneliti tidak membatasi jenis dan lama kerja. Dalam penelitian ini, kuisioner diberikan kepada 180 partisipan. Kuisioner yang dapat diolah sebanyak 120 kuistioner. Demografi dari partisipan yang digambarkan sebagai berikut, partisipan laki-laki $51.7 \%$ dan perempuan sebesar $48.3 \%$. Partisipan berpendidikan S2 dengan presentase tertinggi 91.7\%. Selanjutnya partisipan dengan lama bekerja 5 sampai 2 tahun memiliki presentase tertinggi yaitu $66.7 \%$.

Tabel 1 : Gambaran demografi partisipan

\begin{tabular}{cccc}
\hline Variabel Demografi & Demografi Kategori & Frekuensi & Persentase \\
\hline Jenis Kelamin & Laki-laki & 62 & 51.7 \\
& Perempuan & 58 & 48.3 \\
\cline { 2 - 4 } Pendidikan Terakhir & S1 & 4 & 3.3 \\
& S2 & 110 & 91.7 \\
& S3 & 6 & 5.0 \\
\cline { 2 - 4 } Lama bekerja (Tahun) & $20-15$ & 5 & 4.2 \\
& $15-10$ & 9 & 7.4 \\
& $10-5$ & 26 & 21.7 \\
& $5-1$ & 80 & 66.7 \\
\hline
\end{tabular}

Penelitian ini dilakukan dengan menggumpulkan data di Kementrian Kesehatan. Lokasi pengambilan data adalah berada di dinas kesehatan Pekanbaru, Medan, Jakarta, Banten, Bogor, Bandung, Malang, Surabaya, Makasar, Palembang, Batam, Sulawesi selatan dan yogyakarta. Penelitian dilakukan dengan membagikan kuisioner dalam bentuk google form ke widyaiswara. Pembagian kuisioner dilakukan sejak 14 April 2018 hingga 29 Mei 2018. Pembatasan jadwal pengisian kuisioner dikarenakan adanya keterbatasan waktu peneliti dalam proses penelitian. 


\section{Pengukuran Penelitian \\ Perilaku kerja inovatif}

Alat ukur yang digunakan untuk mengukur variabel perilaku kerja inovatif adalah innovative behaviour scale yang terdiri dari 14 butir (Robert \& Street, 2001). Skala yang digunakan adalah rating scale yang memiliki rentang dari 1 - 4 yang menunjukan jumlah dilakukannya perilaku yang tertera dalam butir alat ukur mulai dari jarang (1), dan sering (4). Alat ukur ini terdiri dari empat dimensi yaitu: oportunity exploration, formative investigation, championing dan application.

Dimensi oportunity exploration diukur menggunakan 3 butir. Skor alpha cronbrach dimensi ini adalah 0.704. Contoh butir pada dimensi opportunity exploration adalah "Saya membuat perubahan untuk materi training". Selanjutnya dimensi generativity yang diukur menggunakan 2 butir. Skor alpha cronbrach dimensi ini adalah 0.438. Salah satu contoh butir pada dimensi ini yaitu "Saya....melakukan analisis kebutuhan training secara sistemantis". Dikarenakan dimensi ini tidak memiliki nilai alpha cronbrach diatas 0.60 maka dimensi ini tidak dipergunakan untuk melakukan analisis selanjutnya.

Dimensi formative investigation yang diukur menggunakan 3 butir. Skor alpha cronbrach dimensi ini adalah 0.614. Salah satu contoh butir pada dimensi ini yaitu "Saya....Memberikan materimateri/ice breaking/permainan baru dalam materi training". Selanjutnya dimensi championing diukur menggunakan 3 butir. Skor alpha cronbrach dimensi ini adalah 0.703. Contoh butir dalam dimensi ini adalah "Saya ... memberikan materi-materi training yang telah saya perbaharui". Dan terakhir dimensi application diukur menggunakan 3 butir. Skor alpha cronbrach dimensi ini adalah 0.854. Salah satu contoh butir dalam dimensi ini adalah "Saya...mengevaluasi/mengidentifikasi kesalahan sistem/metode training yang telah saya berikan".

\section{Modal psikologis}

Alat ukur yang digunakan untuk mengukur variabel modal psikologis adalah The Psychological capital Scale yang terdiri dari 24 butir (Luthans et al, 2007). Skala yang digunakan adalah rating scale yang memiliki rentang dari 1 - 4 yang menunjukan jumlah dilakukannya perilaku yang tertera dalam butir alat ukur mulai dari tidak setuju (1), dan setuju (4). Alat ukur ini terdiri dari empat dimensi yaitu: Hope, self eficacy, optimism dan resiliency.

Dimensi Hope diukur menggunakan 6 butir. Skor alpha cronbach dimensi ini adalah 0.654. Contoh butir positif pada dimensi ini adalah "Saya tergolong trainer berprestasi dan memiliki masa depan yang baik". Sedangkan contoh butir negatif pada dimensi ini yaitu "Peluang karir/pangkat saya saat ini sudah mentok (berhenti sampai disini)".

Dimensi self efficacy diukur menggunakan 6 butir. Skor alpha cronbrach dimensi ini adalah 0.720 . Contoh butir positif pada dimensi ini adalah "Saya selalu dapat menyelesaikan traning dengan baik". Sedangkan contoh butir negatif pada dimensi ini yaitu "Saya kurang yakin dalam mengemukakan pendapat/ide (misalnya, pada saat diskusi mengenai strategi pemasaran training/pembuatan training".

Dimensi optimism diukur menggunakan 4 butir. Skor alpha cronbrach dimensi ini adalah 0.630. Contoh butir positif pada dimensi ini adalah "Saya lebih banyak mengalami peristiwa baik daripada peristiwa buruk". Sedangkan contoh butir negatif pada dimensi ini yaitu "Jumlah keberhasilan yang saya capai lebih sedikit dibandingkan dengan jumlah kegagalan saya". 
Dan terakhir dimensi resiliency diukur menggunakan 5 butir. Skor alpha cronbrach dimensi ini adalah 0.615. Contoh butir positif pada dimensi ini adalah "Pada saat saya mengalami kegagalan/masalah berat, kondisi saya akan kembali seperti sedia kala; bahkan lebih sukses (melebihi kondisi sedia kala)". Sedangkan contoh butir negatif pada dimensi ini yaitu "Ketika ada suatu kendala dalam tugas saya cenderung menunggu solusi/perintah dari rekan/atasan".

\section{Tuntutan dan sumber daya pekerjaan}

Alat ukur yang digunakan untuk mengukur variabel tuntutan dan sumber daya pekerjaan adalah Job demand-Resource scale yang terdiri dari 42 butir (Rotmann, Mostert \& Strydom, 2006). Skala yang digunakan adalah rating scale yang memiliki rentang dari 1- 4 yang menunjukan jumlah dilakukannya perilaku yang tertera dalam butir alat ukur mulai dari jarang (1), dan sering (4). Alat ukur ini terdiri dari lima dimensi growth opportunities, organisational support, dan advancement sebagai dimensi dari sumber daya pekerjaan dan overload dan job insecurity sebagai dimensi dari tuntutan kerja.

Dimensi Growth opportunities adalah dimensi untuk mengukur sumber daya pekerjaan diukur menggunakan 17 butir. Skor alpha cronbrach dimensi ini adalah 0.896. Contoh butir pada dimensi ini adalah "Saya dapat meminta bantuan dari rekan kerja bila perlu". Dimensi organisational support untuk mengukur dimensi pada sumber daya pekerjaan diukur menggunakan 6 butir. Skor alpha cronbrach dimensi ini adalah 0.760. Contoh butir dalam dimensi organizational support adalah "Instansi training menawarkan kesempatan saya dalam pertumbuhan dan perkembangan pribadi". Dimensi advancement adalah dimensi untuk mengukur sumber daya pekerjaan diukur menggunakan 6 butir. Skor alpha cronbrach dimensi ini adalah 0.762. Contoh butir pada dimensi advancement adalah "Pekerjaan saat ini memberikan dukungan finansial cukup baik untuk saya".

Dimensi overload adalah dimensi untuk mengukur tuntutan kerja diukur menggunakan 8 butir. Skor alpha cronbrach dimensi ini adalah 0.626. Contoh butir pada dimensi ini adalah "Saya memiliki terlalu banyak pekerjaan yang harus dilakukan". Dan terkahir dimensi job insecurity adalah dimensi untuk mengukur tuntutan kerja diukur menggunakan 4 butir. Skor alpha conbrach dimensi ini adalah 0.833. Contoh butir pada dimensi ini adalah "Saya dapat memastikan saya tidak akan dikeluarkan sampai akhir tahun ini”.

\section{HASIL DAN PEMBAHASAN}

\section{Gambaran perilaku kerja inovatif pada partisipan}

Untuk memperoleh hasil gambaran data terkait perilaku kerja inovatif peneliti menggunakan pengolahan descriptive statistic. Berdasarkan hasil pengolahan, peneliti mengetahui gambaran perilaku kerja novatif secara keseluruhan pada partisipan dengan nilai rata-rata, $\mathrm{M}=3.169(\mathrm{SD}=$ 0.666). Skala kontinum perilaku kerja inovatif nilai minimal adalah 1 dan maksimal adalah 4 , sehingga nilai tengah adalah 3. Nilai rata-rata perilaku kerja inovatif secara keseluruhan lebih tinggi dibandingkan dengan nilai tengah alat ukur perilaku kerja inovatif. Hal ini berarti bahwa perilaku perilaku kerja inovatif yang tampak pada partisipan tergolong tinggi. Dengan demikian terlihat bahwa partisipan memiliki perilaku kerja inovatif untuk membuat materi pelatihan dan memberikan pelatihan. Untuk mendapatkan gambaran yang lebih jelas pada setiap dimensi perilaku kerja inovatif partisipan dapat dilihat pada Tabel 4.1.1 atau Lampiran.

Berdasarkan analisa deskriptif, diketahui bahwa skor rata-rata dimensi oportunity exploration pada widyaiswara adalah $M=3.195$ dan $S D=0.683$. Skala kontinum oportunity exploration minimal adalah 1 dan maksimal adalah 4. Nilai rata-rata skor oportunity exploration ini cenderung lebih 
tinggi dibandingkan dengan nilai titik tengah alat ukur yaitu 3.00. Artinya, partisipan berinovasi karena memiliki peluang untuk mengeksplor diri lebih jauh.

Berdasarkan analisa deskriptif, diketahui bahwa skor rata-rata dimensi formative investigation pada widyaiswara adalah $M=3.151$ dan $S D=0.703$. Skala kontinum formative investigation minimal adalah 1 dan maksimal adalah 4 . Nilai rata-rata skor formative investigation ini cenderung lebih tinggi dibandingkan dengan nilai titik tengah alat ukur yaitu 3.00. Artinya, partisipan memiliki perilaku inovasi karena dapat keluar dari ide-ide lama dalam mengembangkan materi training.

Berdasarkan analisa deskriptif, diketahui bahwa skor rata-rata dimensi Championing pada widyaiswara adalah $M=3.203$ dan $S D=0.620$. Skala kontinum Championing minimal adalah 1 dan maksimal adalah 4. Nilai rata-rata skor Championing ini cenderung lebih tinggi dibandingkan dengan nilai titik tengah alat ukur yaitu 3.00. Artinya, partisipan dapat mengasah kemampuan dalam berinovasi.

Berdasarkan analisa deskriptif, diketahui bahwa skor rata-rata dimensi application pada widyaiswara adalah $M=3.157$ dan $S D=0.618$. Skala kontinum application minimal adalah 1 dan maksimal adalah 4. Nilai rata-rata skor application ini cenderung lebih tinggi dibandingkan dengan nilai titik tengah alat ukur yaitu 3.00. Artinya, partisipan dapat mengaplikasikan hasil dari ide-ide baru terkait dengan materi training.

\section{Gambaran modal psikologis pada partisipan}

Untuk memperoleh hasil gambaran data terkait Modal Psikologis peneliti menggunakan pengolahan descriptive statistic. Berdasarkan hasil pengolahan, peneliti mengetahui gambaran Modal Psikologis secara keseluruhan pada partisipan dengan nilai rata-rata, $\mathrm{M}=2.589(\mathrm{SD}=1.044)$. Skala kontinum Modal Psikologis nilai minimal adalah 1 dan maksimal adalah 4, sehingga nilai tengah adalah 3. Nilai rata-rata Modal Psikologis secara keseluruhan lebih rendah dibandingkan dengan nilai tengah alat ukur Modal Psikologis. Hal ini berarti bahwa perilaku Modal Psikologis yang tampak pada partisipan tergolong rendah. Hal tersebut menggambarkan bahwa Modal Psikologis tidak terlalu mempengaruhi partisipan dalam berinovasi untuk membuat materi pelatihan. Untuk mendapatkan gambaran yang lebih jelas pada setiap dimensi Modal Psikologis partisipan dapat dilihat pada Tabel 4.1.2 atau Lampiran.

Berdasarkan analisa deskriptif, diketahui bahwa skor rata-rata dimensi Self efficacy adalah $M=$ 2.594 dan $S D=1.048$. Skala kontinum minimal adalah 1 dan maksimal adalah 4. Sehingga nilai tengah adalah 3. Nilai rata-rata skor Self efficacy ini cenderung rendah dibandingkan dengan nilai titik tengah alat ukur yaitu 3.00. Artinya, partisipan kurang percaya dengan dirinya sendiri dan kurang termotivasi untuk melakukan pekerjaan atau pelatihan.

Berdasarkan analisa deskriptif, diketahui bahwa skor rata-rata dimensi Resiliency pada widyaiswara adalah $M=2.482$ dan $S D=1.081$. Skala kontinum minimal adalah 1 dan maksimal adalah 4. Sehingga nilai tengah adalah 3. Nilai rata-rata skor Resiliency ini cenderung rendah dibandingkan dengan nilai titik tengah alat ukur yaitu 3. Dengan demikian, partisipan kurang mampu bangkit dari keterpurukan dan mengambil nilai positif dari setiap masalah yang dihadapi.

Berdasarkan analisa deskriptif, diketahui bahwa skor rata-rata dimensi Hope pada widyaiswara adalah $M=2.599$ dan $S D=1.052$. Skala kontinum minimal adalah 1 dan maksimal adalah 4 . Sehingga nilai tengah adalah 3 . Nilai rata-rata skor Hope ini cenderung rendah dibandingkan 
dengan nilai titik tengah alat ukur yaitu 3. Dengan demikian, dapat dilihat partisipan kurang dalam menentukan tujuan dalam pekerjaanya.

Berdasarkan analisa deskriptif, diketahui bahwa skor rata-rata dimensi Optimism pada widyaiswara adalah $M=2.643$ dan $S D=1.059$. Skala kontinum minimal adalah 1 dan maksimal adalah 4. Sehingga nilai tengah adalah 3. Nilai rata-rata skor Optimism ini cenderung rendah dibandingkan dengan nilai titik tengah alat ukur yaitu 3. Artinya, partisipan masih meyakini bahwa kejadian buruk yang menimpanya akan terjadi terus-menerus dan tidak ada perubahan dalam dirinya.

\section{Gambaran tuntutan kerja pada partisipan}

Untuk memperoleh hasil gambaran data terkait tuntutan kerja peneliti menggunakan pengolahan descriptive statistic. Berdasarkan hasil pengolahan, peneliti mengetahui gambaran tuntutan kerja secara keseluruhan pada partisipan dengan nilai rata-rata, $\mathrm{M}=2.836(\mathrm{SD}=0,324)$. Skala kontinum tuntutan kerja nilai minimal adalah 1 dan maksimal adalah 4, sehingga nilai tengah adalah 3. Nilai rata-rata tuntutan kerja secara keseluruhan lebih rendah dibandingkan dengan nilai tengah alat ukur tuntutan kerja. Hal ini berarti bahwa perilaku Job demand yang tampak pada partisipan tergolong rendah. Dengan demikian terlihat bahwa partisipan dengan tekanan kerja kurang dapat berinovasi. Hal ini dikarenakan kurangnya tekanan waktu, kurangnya kesulitan dalam membangun relasi dengan orang baru dan pekerjaan tidak mempengaruhi kehidupan pribadi. Untuk mendapatkan gambaran yang lebih jelas pada setiap dimensi tuntutan kerja partisipan dapat dilihat pada Tabel 4.1.3 atau Lampiran.

Berdasarkan analisa deskriptif, diketahui bahwa skor rata-rata dimensi Overload pada widyaiswara adalah $M=2.376$ dan $S D=0.346$. Skala kontinum minimal adalah 1 dan maksimal adalah 4. Sehingga nilai tengah adalah 3. Nilai rata-rata skor Overload ini cenderung rendah dibandingkan dengan nilai titik tengah alat ukur yaitu 3.00. Dengan demikian, partisipan kurang mengalami kendala dalam kecepatan,beban emosional dan banyaknya pekerjaan yang mereka kerjakan.

Berdasarkan analisa deskriptif, diketahui bahwa skor rata-rata dimensi Job Insecurity pada widyaiswara adalah $M=3.295$ dan $S D=0.469$. Skala kontinum minimal adalah 1 dan maksimal adalah 4. Sehingga nilai tengah adalah 3. Nilai rata-rata skor Job Insecurity ini cenderung tinggi dibandingkan dengan nilai titik tengah alat ukur yaitu 3.00. Artinya, partisipan percaya dengan masa depan yang akan mereka hadapi terkait dengan pekerjaan yang mereka jalani saat ini.

\section{Gambaran sumber Daya Pekerjaan pada Partisipan}

Untuk memperoleh hasil gambaran data terkait sumber daya pekerjaan peneliti menggunakan pengolahan descriptive statistic. Berdasarkan hasil pengolahan, peneliti mengetahui gambaran sumber daya pekerjaan secara keseluruhan pada partisipan dengan nilai rata-rata, $\mathrm{M}=3.147$ ( $\mathrm{SD}=$ 0.295). Skala kontinum sumber daya pekerjaan nilai minimal adalah 1 dan maksimal adalah 4, sehingga nilai tengah adalah 3. Nilai rata-rata sumber daya pekerjaan secara keseluruhan lebih tinggi dibandingkan dengan nilai tengah alat ukur sumber daya pekerjaan. Hal ini berarti bahwa perilaku sumber daya pekerjaan yang tampak pada partisipan tergolong tinggi. Dengan demikian terlihat bahwa partisipan dengan tekanan kerja kurang dapat berinovasi. Hal ini dikarenakan terdapat sumber daya yang dapat memenuhi kebutuhan partisipan. Seperti upah yang cukup, hubungan yang baik dengan atasan dan rekan kerja serta memiliki kesempatan untuk mengembangkan diri dalam memenuhi kebutuhan diklat. Untuk mendapatkan gambaran yang lebih jelas pada setiap dimensi Job resource partisipan dapat dilihat pada Tabel 4.1.4 atau Lampiran. 
Berdasarkan analisa deskriptif, diketahui bahwa skor rata-rata dimensi Growth Opportunity pada widyaiswara adalah $M=3.181$ dan $S D=0.323$. Skala kontinum minimal adalah 1 dan maksimal adalah 4. Sehingga nilai tengah adalah 3. Nilai rata-rata skor Growth Opportunity ini cenderung rendah dibandingkan dengan nilai titik tengah alat ukur yaitu 3,00. Artinya, partisipan memiliki peluang dan kemandirian dalam belajar pada pekerjaan ketika berada dalam tekanan pekerjaan.

Berdasarkan analisa deskriptif, diketahui bahwa skor rata-rata dimensi Advancement pada widyaiswara adalah $M=3.177$ dan $S D=0.295$. Skala kontinum minimal adalah 1 dan maksimal adalah 4. Sehingga nilai tengah adalah 3. Nilai rata-rata skor Advancement ini cenderung tinggi dibandingkan dengan nilai titik tengah alat ukur yaitu 3,00. Artinya, partisipan mendapatkan kesempatan untuk mengemabngkan diri dengan pelatihan yang dilaksanakan di organisasi serta partisipan mendapatkan upah yang cukup untuk memenuhi kebutuhan pribadi.

Berdasarkan analisa deskriptif, diketahui bahwa skor rata-rata dimensi Organizational support pada widyaiswara adalah $M=3.081$ dan $S D=0.350$. Skala kontinum minimal adalah 1 dan maksimal adalah 4. Sehingga nilai tengah adalah 3. Nilai rata-rata skor Organizational support pini cenderung tinggi dibandingkan dengan nilai titik tengah alat ukur yaitu 3.00. Artinya, ketika partisipan mengalami tekanan dalam pekerjaan partisipan dapat berkomunikasi dengan tepat,menjalin hubungan dengan mentor/atasan dan mengambil keputusan dengan baik.

Tabel 2 : Gambaran variabel pada partisipan

\begin{tabular}{lcc}
\hline \multicolumn{1}{c}{ Variabel } & Mean & SD \\
\hline Perilaku Kerja Inovatif & & \\
Opportunity exploration & 3.195 & 0.683 \\
$\quad$ formative Investigation & 3.151 & 0.703 \\
$\quad$ Championing & 3.203 & 0.62 \\
Application & 3.157 & 0.618 \\
Perilaku kerja inovatif total & 3.169 & 0.666 \\
Modal Psikologis & & \\
Self efficacy & 2.594 & 1.048 \\
Resiliency & 2.482 & 1.081 \\
Hope & 2.599 & 1.052 \\
Optimism & 2.643 & 1.059 \\
$\quad$ Modal psikologis total & 2,589 & 1,044 \\
Tuntutan Kerja & & \\
$\quad$ Overload & 2.376 & 0.346 \\
$\quad$ Job insecurity & 3.295 & 0.469 \\
Tuntutan kerja total & 2.836 & 0.324 \\
Sumber Daya Pekerjaan & & \\
Organizational support & 3.081 & 0.35 \\
Advancement & 3.177 & 0.295 \\
Sumber daya pekerjaan total & 3.147 & 0.295 \\
\hline
\end{tabular}




\section{Uji Hipotesis Hubungan Modal Psikologis dengan Perilaku Kerja Inovatif}

Berdasarkan hasil uji normalitas, sebaran data pada variabel modal psikologis dan perilaku kerja inovatif tidak normal, yaitu pada variabel perilaku kerja inovatif $(\mathrm{p}=0.000<0.05)$ dan pada variabel modal psikologis $(\mathrm{p}=0.012<0.05)$. Oleh karena itu uji korelasi spearman digunakan untuk menguji hubungan antara variabel modal psikologis dengan perilaku kerja inovatif. Pada penelitian ini modal psikologis sebagai variabel bebas dan perilaku kerja inovatif adalah variabel terikat.

Dengan menggunakan uji metode korelasi Spearman Brown, pada level alpha 0,05, ada korelasi yang signifikan antara modal psikologis terhadap perilaku kerja inovatif $(M d=3.166), r=0.219$, $\mathrm{p}=0.007<0,01)$. Artinya, semakin partisipan memiliki modal psikologis, semakin tinggi perilaku kerja inovatif pada dirinya.

Berdasarkan analisa yang dilakukan pada dimensi modal psikologis, dimensi resiliency memiliki nillai $(\mathrm{r}=0.244, \mathrm{p}=0.003<0.01$ ) lebih menunjukan adanya korelasi yang signifikan dibandingkan dengan dimensi self efficacy, hope dan optimism. Artinya, partisipan dapat beradaptasi dengan baik pada perubahan, dan partisipan mudah untuk bangkit kembali dari masalah yang dihadapi sehingga partisipan dapat berinovasi dengan baik.

\section{Uji Hipotesis Hubungan Tuntutan Kerja dengan Perilaku Kerja Inovatif}

Berdasarkan hasil uji normalitas, sebaran data pada variabel tuntutan kerja dengan perilaku kerja inovatif tidak normal, yaitu pada variabel perilaku kerja inovatif $(\mathrm{p}=0.000<0.05)$ dan pada variabel tuntutan kerja $(\mathrm{p}=0.002<0.05)$. Oleh karena itu uji korelasi spearman digunakan untuk menguji hubungan antara variabel tuntutan kerja dan perilaku kerja inovatif. Pada penelitian ini tuntutan kerja sebagai variabel bebas dan perilaku kerja inovatif adalah variabel terikat.

Dengan menggunakan uji metode korelasi Spearman Brown, pada level alpha 0,05, ada korelasi yang signifikan antara tuntutan kerja terhadap perilaku kerja inovatif $(M d=3.00), r=0.193, p=$ $0.018<0.05)$. Artinya, semakin partisipan memiliki tuntutan kerja semakin tinggi perilaku kerja inovatif pada dirinya.

Berdasarkan analisa yang dilakukan pada dimensi tuntutan kerja, dimensi job insecurity memiliki nillai $(\mathrm{r}=0.241, \mathrm{p}=0.003<0.01)$ lebih menunjukan adanya korelasi yang signifikan dibandingkan dengan dimensi overload. Artinya, partisipan dapat berinovasi dengang memastikan bahwa angka kredit dalam pelaksanaan diklat tetap stabil.

\section{Uji Hipotesis Hubungan Sumber Daya Pekerjaan dengan Perilaku Kerja Inovatif}

Berdasarkan hasil uji normalitas, sebaran data pada variabel sumber daya pekerjaan dengan perilaku kerja inovatif tidak normal, yaitu pada variabel perilaku kerja inovatif $(\mathrm{p}=0.000<0.05)$ dan pada variabel sumber daya pekerjaan $(\mathrm{p}=0.001<0.05)$. Oleh karena itu uji korelasi spearman digunakan untuk menguji hubungan antara variabel sumber daya pekerjaan dan perilaku kerja inovatif. Pada penelitian ini sumber daya pekerjaan sebagai variabel bebas dan perilaku kerja inovatif adalah variabel terikat.

Dengan menggunakan uji metode korelasi Spearman Brown, pada level alpha 0,05, ada korelasi yang signifikan antara sumber daya pekerjaan terhadap perilaku kerja inovatif $(M \mathrm{~d}=3.00), \mathrm{r}=$ $0.241, \mathrm{p}=0.003<0.01)$. Artinya, semakin partisipan memiliki sumber daya pekerjaan semakin tinggi perilaku kerja inovatif pada dirinya. 
Berdasarkan analisa yang dilakukan pada dimensi sumber daya pekerjaan, dimensi advancement memiliki nillai $(\mathrm{r}=0.244, \mathrm{p}=0.003<0.01)$ lebih menunjukan adanya korelasi yang signifikan dibandingkan dengan dimensi growth opportunity dan organizational support. Artinya, partisipan dapat berinovasi terkait dengan upah yang didapatkan. Selain itu organisasi memberikan kesempatan untuk mengikuti pelatihan/training pada partisipan.

Tabel 3 : Uji hipotesis variabel

\begin{tabular}{lcc}
\hline Variabel & $\mathrm{R}$ & $\mathrm{Sig}$ \\
\hline Modal psikologis & 0.219 & 0.007 \\
Self efficacy & 0.204 & 0.012 \\
Resiliency & 0.244 & 0.003 \\
Optimism & 0.129 & 0.116 \\
Hope & 0.183 & 0.025 \\
Tuntutan kerja & 0.193 & 0.018 \\
Overload & 0.095 & 0.249 \\
Job insecurity & 0.241 & 0.003 \\
Sumber daya pekerjaan & 0.241 & 0.003 \\
Growth opportunity & 0.242 & 0.003 \\
Organizational support & 0.229 & 0.005 \\
Advancement & 0.244 & 0.003 \\
\hline
\end{tabular}

\section{KESIMPULAN DAN SARAN}

Berdasarkan hasil gambaran perilaku kerja inovatif secara keseluruhan pada widyaiswara menunjukan perilaku kerja inovatif yang tinggi. Hal ini terjadi dikarenakan perubahan dan perkembangan teknologi yang semakin canggih, dan adanya kebijakan untuk berinovasi pada widyaiswara. terbangunnya sistem informasi yang menunjang kediklatan. Widyaiswara saat ini tidak lagi menggunakan berkas-berkas untuk penilaian angka kredit melainkan meggunakan microsoft office dan excel. Namun, untuk beberapa dinas telah berinovasi dengan membuat sebuah sistem penilaian dengan aplikasi yang memudahkan widyaiswara dalam memasukan data. Perubahan lainnya adalah terbangunya sistem informasi berbasis web sehingga memudahkan widyaiswara dalam memonitor program diklat. Selain itu, widyaiswara kini lebih banyak menggunakan media internet untuk mengembangkan materi diklat, serta menggunakan video dan gambar animasi dalam slide powerpoint sebagai metode dalam diklat sehingga diklat tidak lagi monoton (observasi, 12 Juli, 2018).

Dari hasil penelitian diketahui bahwa sumber daya pekerjaan berhubungan positif dengan perilaku kerja inovatif. Diketahui dimensi advancement salah satu dimensi sumber daya pekerjaan lebih menunjukan adanya korelasi yang signifikan dengan perilaku kerja inovatif dibandingkan dengan dimensi growth opportunity dan organizational support. Hal ini dapat menunjukkan bahwa widyaiswara yang memiliki lebih banyak sumber daya dalam pekerjaan akan mengembangkan tingkat inovasi untuk meningkatkan angka kredit agar mendapatkan upah yang sesuai. Selain itu, hasil penelitian menunjukan bahwa tuntuan kerja memiliki hubungan dengan perilaku kerja inovatif. Diketahui bahwa dimensi job insecurity lebih memiliki korelasi dibandingkan dimensi overload dalam memprediksi perilaku kerja inovatif. Hal ini dapat memperlihatkan widyaiswara memastikan angka kredit tetap stabil dengan melakukan inovasi pada materi dan penyelenggaraan diklat.

Hal ini memperkuat hasil penelitian Dedidu, Leka, \& Jain (2018) yang menunjukan adanya hubungan antara tuntutan kerja dan sumber daya pekerjaan dengan perilaku kerja inovatif. Hasil penelitian Dedidu, Leka, \& Jain (2018) juga menunjukan sumber daya pekerjaan lebih memiliki 
korelasi pada perilaku kerja inovatif. Gambaran pada penelitian ini menunjukan keseluruhan karyawan lebih inovatif dalam menghadapi tuntutan yang lebih tinggi ketika mereka memiliki sumber daya pekerjaan yang tinggi.

Penelitian yang dilakukan oleh Mishra et al. (2017) mendapatkan hasil bahwa modal psikologis dapat memprediksi perilaku kerja inovatif. Hasil dalam penelitian ini juga menemukan hubungan positif antara modal psikologis dan perilaku kerja inovatif, Hal ini dapat memperlihatkan modal psikologis dapat membantu widyaiswara dalam mengatasi berbagai tantangan terkait dengan perilaku kerja inovatif.

Berdasarkan analisa yang dilakukan pada dimensi modal psikologis, dimensi resiliency lebih menunjukan adanya korelasi yang signifikan dalam memprediksi perilaku kerja inovatif dibandingkan dengan dimensi self efficacy, hope dan optimism. Hal ini memperlihatkan bahwa widyaiswara dapat beradaptasi dengan baik pada perubahan, dan widyaiswara mudah untuk bangkit kembali dari masalah yang dihadapi.

Pada penelitian lainnya membahas hubungan tuntutan dan sumber daya pekerjaan pada perilaku kerja inovatif oleh Martin, Salanova \& Peiro (2007) ditemukan hasil bahwa terdapat hubungan antara tuntutan dan sumber daya pekerjaan dengan perilaku kerja inovatif. Gambaran pada penelitian ini menunjukan keseluruhan karyawan lebih inovatif dalam menghadapi tuntutan yang lebih tinggi ketika mereka memiliki sumber daya pekerjaan yang tinggi.

Berdasarkan hasil uji hipotesis modal psikologis, tuntutan kerja dan sumber daya pekerjaan memiliki hubungan positif dan signifikan dengan perilaku kerja inovatif. Hasil penelitian menjelaskan bahwa sumber daya pekerjaan lebih memiliki hubungan dengan perilaku kerja inovatif dibandingkan dengan modal psikologis dan tuntutan kerja. Itu artinya, sumber daya pekerjaan lebih dapat memperdiksi perilaku kerja inovatif dibandingkan dengan modal psikologis dan tuntutan kerja. Artinya partisipan dapat berinovasi apabila sumber daya dalam pekerjaan terpenuhi dengan baik. Dengan memiliki kesempatan untuk mengembangkan diri, memiliki hubungan yang baik dengan atasan dan rekan kerja serta mendapatkan upah yang cukup.

\section{Saran}

Pada penelitian Dedidu, et al. (2018) menjelaskan terdapat hubungan antara tuntutan dan sumber daya pekerjaan dengan perilaku kerja inovatif. Namun tidak hanya tuntutan dan sumber daya pekerjaan, penelitian ini juga sedikit menyinggung tentang tuntutan dan control pada pekerjaan Diharapkan pada penelitian selanjutnya dapat meneliti terkait tuntutan dan control pada pekerjaan dengan perilaku kerja inovatif pada partisipan yang berbeda.

Pada hasil penelitian ini diketahui bahwa terdapat hubungan antara sumber daya pekerjaan dan perilaku kerja inovatif pada widyaiswara. Diketahui dimensi advancement salah satu dimensi pada sumber daya pekerjaan menunjukan korelasi yang lebih tinggi dibandingkan dengan growth opportunity dan organizational support. Sehingga disarankan untuk widyaiswara lebih meningkatkan inovasi dimulai dari diri sendiri dan terus meningkatkan skor kredit dengan mengembangkan diri serta membuat diklat lebih menarik. 


\section{Ucapan Terima Kasih (Acknowledgement)}

Penulis mengucapkan terima kasih kepada beberapa pihak yang telah berpartisipasi dalam penelitian ini, terutama pada Badan Pelatihan Kesehatan di Kementrian Kesehatan yang telah memberikan izin untuk membagikan kuesioner kepada widyaiswara. Dan kepada para partisipan yang telah ikut berpartisipasi dalam penelitian ini.

\section{REFERENSI}

Ajum, A. M., Ahmed, J. S., \& Karim, J. (2014). Do psychological capitalbilities really matter? The combine effect of psychological capital and peace of mind on work centarility and in role performance. Pakistan Journal of Commerce and Social Sciences, $8(2), 502-520$.

Bakker, B, A., Demeuroti, E., Hakanen, J. J., \& Xanthoupoulou, D. (2007). Job resource boost work engagement particulary when job demand are high. Journal of Educational Psychology, 99(2), 274-284.

Bakker, B. A., \& Demeuroti, E. (2017). Job demand-resource theory: taking stock and looking forward. Journal of Occupational Health Psychology, 22(3), 273-285.

Dedidu, V., Leka, S., \& Jain, A. (2018). Job demand, job resource and innovative work behavior: A europan union study. Europan Journal of Work and Organizational Psychology, (1),114.

De Jong, J. \& Hartog, D. D. (2010). Measuring inovative work behavior. Journal Creative and Innovation Management, 19(1), 23-36.

Fay, D., Bagotiriute, R., Urbach, T., West, A, M., \& Dawson, J. (2017). Differential effect of workplace stressor on innovation:an integrated perspective of cyebernetics and coping. International Journal of Stress Management,23(1), 2-41.

He, L. W. (2013). Organizational innovative climmate, innovative behavior and the mediating role of psychological capital: the case of creative talent. Journal of Organizational Behavior, 4(4), 50-44.

Luthans, F. (2002). The need for and meaning of positive of organizational behavior. Journal of Organizational Behavior, 23(6), 795-706

Luthans, F., Luthans, K., \& Luthans, B. (2004). Positive psychological capital: going beyond human and social capital. Journal of Psychological Educational Psychology, 47, 45-50.

Luthans, F., Youssef, C. M., \& Avolio, B. J. (2007). Psychological capital: Developing the human competitive edge. Oxford, UK: Oxford University Press.

Martin, P., Marisa, S., \& Peiro, M. J. (2007). Job demand,job resources and individual innovation at work: Going beyond karsek's model. Psicothema, 19(4), 621-626.

Mishra, P., Bhatnagar, J., Gupta, R., \& Wadswoth, M. S. (2017). How work-family enrichment influence innovative work behavior: Role of psychological capital and supervisory support. Journal of Management and Organisation, 10, 1-23.

Naz, F., \& Murad, S. H. (2017). Innoavtive teaching has a positif impact on the performance on diverse Student. Journal Sage, 1(1), 1-8.

Peraturan Lembaga Adminstrasi Negara nomor 8 tahun 2015 tentang Jabatan Fungsional Widyaiswara dan Angka Kreditnya.

Peter E. D., Love, Zahir, I., Craig, S., \& Marinos, T. (2007). Influence of job demands, job control and social support on information systems professionals' psychological well-being. International Journal of Manpower, 28(6), 513-528.

Schaufeli, W. B., \& Bakker A. B. (2004). Job demands, job resources, and their relationship with burnout and engagement:A multi-sample study. Journal of Organizational Behavior, 25, 293-315. 
Westman, et al. (2010). Sabbatical leave: Who gains and how much. Journal of Applied Psychology, 1-12.

Woerkom, V. M., Nishi, H. L., \& Bakker, B. A. (2016). Acummulative job demand and support for strength use: Fine tuning the job demand-resource model using conversation of resource theory. Journal of Applied Psychology. 101(1) 141-150. 